\title{
Synthesis of Novel 4-Thiazolidinone and Bis-Thiazalidin-4-One Derivatives Derived from 4-Amino-Antipyrine and Evaluated as Inhibition of Purine Metabolism Enzymes by Bacteria
}

\author{
Reda M. Abdel Rahman'1, Abdulrahman S. Alharbi', Nawaa A. Alshammari1,2* \\ ${ }^{1}$ Department of Chemistry, Faculty of Science, King Abdul Aziz University, Jeddah, Saudi Arabia \\ ${ }^{2}$ Department of Chemistry, Faculty of Science, Northern Borders University, Rafha, Saudi Arabia \\ Email: *ro-0s@hotmail.com
}

How to cite this paper: Rahman, R.M.A., Alharbi, A.S. and Alshammari, N.A. (2019) Synthesis of Novel 4-Thiazolidinone and Bis-Thiazalidin-4-One Derivatives Derived from 4-Amino-Antipyrine and Evaluated as Inhibition of Purine Metabolism Enzymes by Bacteria. International Journal of Organic Chemistry, 9, 85-95.

https://doi.org/10.4236/ijoc.2019.92008

Received: March 13, 2019

Accepted: June 9, 2019

Published: June 12, 2019

Copyright $\odot 2019$ by author(s) and Scientific Research Publishing Inc. This work is licensed under the Creative Commons Attribution International License (CC BY 4.0).

http://creativecommons.org/licenses/by/4.0/

\begin{abstract}
Novel 4-thiazolidione and 1,4-bis-thiazolidinone derivatives bearing antipyrine moiety have been obtained from condensation of 4-aminoantipyrine 1 with aromatic/heteroaldehydes followed by cycloaddition with mercaptoacetic acid in nonpolar solvents. Structure of the products has been deduced upon their elemental analysis and spectral measurements. Most of the targets evaluated as enzymatic effect towards some bacteria (E. coli) in compare with Xanthine oxidase (from buttermilk) where the role of compounds is an inhibition of purine metabolism enzymes caused by $E$. coli.
\end{abstract}

\section{Keywords}

Synthesis, 4-Thiazolidinones, Antipyrine, Inhibition of Purine Metabolism Enzymes, Bacteria

\section{Introduction}

The use of 4-thiazolidinone as chemical fertilizers to increase the yield of crops and pesticides to eliminate all kinds of parasites able to attack the cultivation is becoming more and more important because of the great problem facing the world to provide food to an increasing population [1]. Recently, 4-thiazolidinones derivatives exhibited a wide spectrum of biological medicinal and pharmacological properties such as antibacterial, antioxidant, and hypoglycemic activity [2]. Most of 4-thiazolidinones synthesized exhibited antifungal and antibacterial ac- 
tivity [3] [4] [5]. 4-Amino-antipyrine showed various important properties as an anti-inflammatory [6], antimicrobial [7] and as an inhibitor of mild steel corrosion in $\mathrm{HCl}$ solution [8]. Also, it's used to eliminate some metal ions as an antifungal agent [9]. Its interest that Schiff's base analogs of 4-amino-antipyrine exhibited antibacterial and cytotoxic activities [10]. Because of these important results and variables observations, the present work prompted us to synthesize some new Schiff's bases derived from condensation of 4-amino-antipyrine with aromatic aldehydes followed by cycloaddition with thioacetic acid to obtain the thiazolidin-4-ones in view of their an enzymatic as inhibition of purine metabolism enzymes caused by $E$. coli. It is known that $E$. coli strains do not cause disease, but virulent strains can cause gastroenteritis, urinary tract infections, neonatal meningitis, hemorrhagic colitis, and Crohn's disease. Common signs and symptoms include severe abdominal cramps, diarrhea, hemorrhagic colitis, vomiting, and sometimes fever. Some strains of $E$. coli, for example, O157:H7, can produce Shiga toxin (classified as a bioterrorism agent). This toxin causes premature destruction of the red blood cells, which then clog the body's filtering system, the kidneys, causing hemolytic-uremic syndrome (HUS). For these reasons, we focused on synthesize some compounds act as inhibitors for E. coli [11].

\section{Chemistry}

The Schiffs base of 4-amino-antipyrine is a group of systems showed a wide range of biological activities having the azomethine $(-\mathrm{N}=\mathrm{CH}-)$ active pharmacophore, which plays major roles in their bio-active properties [10]. Also, the presence of cyclic (NCS-C=O) group in thiazolidin-4-ones often enhances those biological and pharmacological properties [12] [13] [14] [15]. Similarly, condensation of 4-aminoantipyrine (1) with selective halogenated aromatic aldehydes and/or heteroaldehydes in refluxing EtOH, yielded the Schiff's base 2a-f (Scheme 1).

The main aim of the present work is to synthesize of new 4-thiazolidinone bearing antipyrine moiety. Thus, cycloaddition reaction of mercaptoacetic acid with a Schiff's bases $2 \mathbf{a}, \mathbf{e}, \mathbf{f}$ in refluxing with non-polar solvent as dioxane produced 3-(1'-phenyl-2',3'-dimethyl-5'-oxo-pyrazol-4'-yl) thiazolidin-4-ones (3) (Scheme 1).

Due to the order of nucleophilicity as $\mathrm{S}>\mathrm{O}>\mathrm{N}>\mathrm{C}$, the formation of compounds 3 may be by attack of $\mathrm{S}^{-}$on a more electrophilic carbon of Schiff's bases 2 followed by elimination of one molecule of $\mathrm{H}_{2} \mathrm{O}$ (Figure 1).

On other hand, condensation of 4-aminoantipyrine (1) with 1,4-terphthaldehyde (2:1 by mole) in refluxed EtOH, afforded 4,4'-((1,4-phenylenebis (methaneylylidene))bis(azaneylylidene))bis(1,5-dimethyl-2-phenyl-1,2-dihydro-3 $H$-pyrazol-3one) (4) (Scheme 2).

Similarly, cycloaddition reaction of bis compound 4 with mercaptoacetic acid in refluxing dioxane furnished 2,2'-(1,4-phenylene)bis(3-(1,5-dimethyl-3-oxo-2phenyl-2,3 -dihydro-1 $H$-pyrazol-4-yl)thiazolidin-4-one) (5) (Scheme 2). Compound 5 also obtained from refluxing of compound 1 with 1,4-terphthaldehyde 
(2:1 by mole) in excess mercaptoacetic acid in abs. EtOH with a few drops of piperidine for a long time (Scheme 2).

Formation of compound $\mathbf{5}$ may be as a nucleophilic attack of $\mathrm{S}^{-}$on a more electrophilic center of Schiff base 4 to give the thioacetic acid derivative, which upon refluxing gave the 4-thiazolidinone via losing of $\mathrm{H}_{2} \mathrm{O}$ (Figure 2).

\section{Results and Discussion}

Former structure of the new compounds 2-5 established from corrected elemental analysis and their spectral data. The UV spectrum of compound 2a recorded the absorption band at $\lambda_{\max } 395 \mathrm{~nm}$, indicated the formation of bio-conjugated systems ( $\mathrm{N}=\mathrm{CH}-$ ). FT-IR spectra of Schiff bases 2 exhibited $\bar{v}$ at $3175-3040 \& 3035-3025 \mathrm{~cm}^{-1}$ for stretching of aromatic $\mathrm{CH}$, with an intense band at $\bar{v} 1680 \mathrm{~cm}^{-1}$ for $\mathrm{C}=\mathrm{O}$.
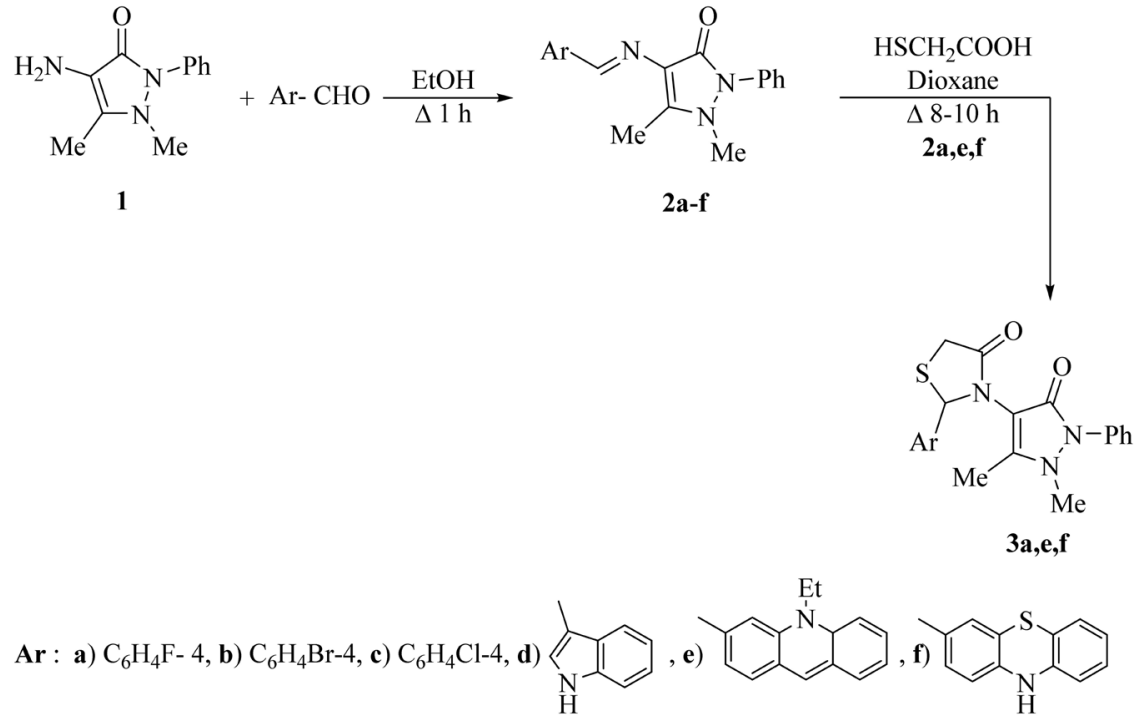

Scheme 1 . Synthesis of compounds $\mathbf{2 a - f}$ and $\mathbf{3 a}, \mathbf{e , f}$.

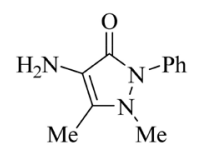

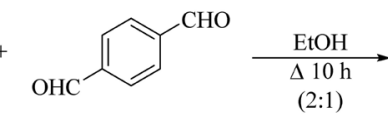

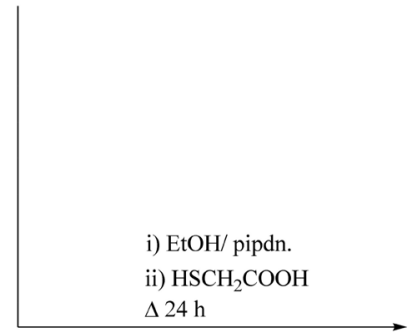

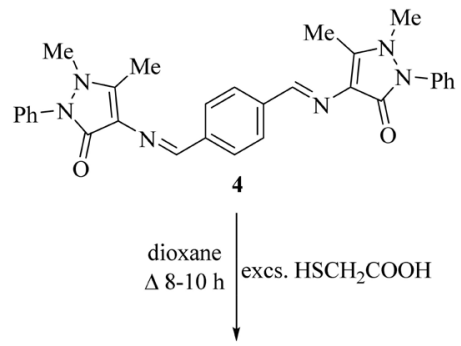

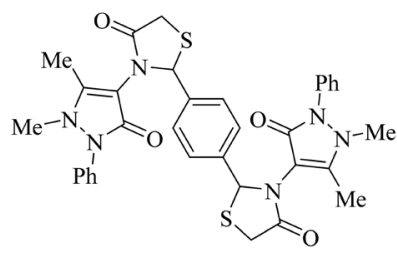

Scheme 2. Synthesis of compounds 4 and 5. 


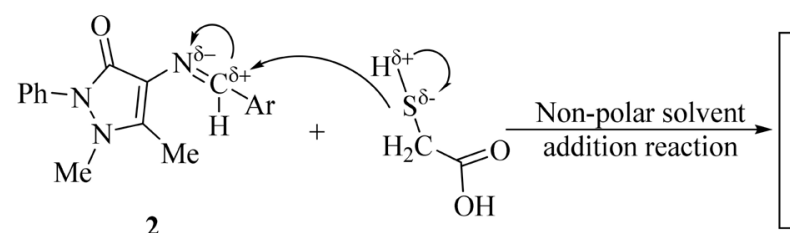

2<smiles>Cc1c([NH2+]CCC(=O)O)c(=O)n(-c2ccccc2)n1C</smiles>
$-\mathrm{H}_{2} \mathrm{O}$<smiles>Cc1c(N2CC([Al])SC2=O)c(=O)n(-c2ccccc2)n1C</smiles>

Figure 1. Formation of compound 3 from 2.
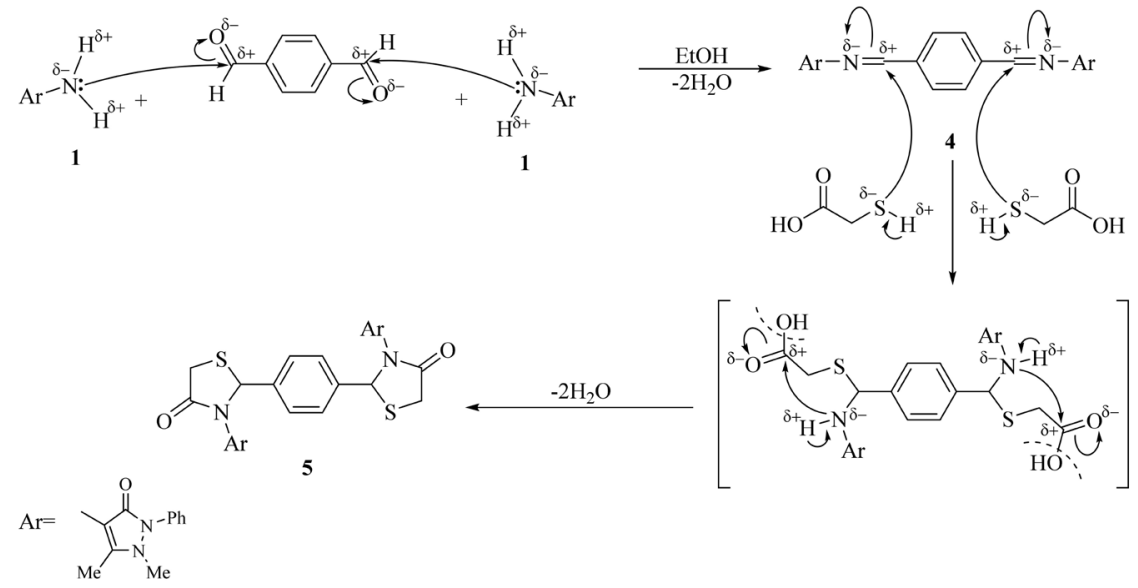

Figure 2. Formation of compound 5 from 4.

Besides, presence of $\bar{v}$ at $1590-1575 \mathrm{~cm}^{-1}$ for $\mathrm{C}=\mathrm{N}$ and $2980-2915 \mathrm{~cm}^{-1}$ (stretching modes) with the deformation of aliphatic $\mathrm{CH}_{3}$ at $\bar{v} 1480-1440 \mathrm{~cm}^{-1}$.

${ }^{1} \mathrm{H}$ NMR spectra of compound 2a display mainly of two sharp signals at $\delta 2.25$ and $3.0 \mathrm{ppm}$ for N-Me \& C-Me protons. Also, it showed $\delta$ at $6.80-7.90 \mathrm{ppm}, 8.2$ - $8.5 \mathrm{ppm}$ for aromatic protons with $d, d$ of F-adjacent aromatic protons, besides, $\delta$ at 9.4 and $6.3 \mathrm{ppm}$ attribute for $\mathrm{CH}=\mathrm{N}$ protons. Moreover, mass fragmentation pattern of compound $3 \mathrm{a}$ recorded a molecular ion peak with the base peak at $\mathrm{m} / \mathrm{z} 95$ attribute to $\mathrm{C}_{6} \mathrm{H}_{4} \mathrm{~F}$ ion (Figure 3 ).

UV absorption spectra of compounds 3 showed $\lambda_{\max } 275 \mathrm{~nm}$, lower than the corresponding Schiff's bases 2 . IR spectra of both the compounds $3 \& 5$ showed the absorption bands at $\bar{v}$ at $1720,1680 \mathrm{~cm}^{-1}$ for true $\mathrm{C}=\mathrm{O}$, with lacks of $\mathrm{NH}$ groups and or $\mathrm{CH}=\mathrm{N} .{ }^{1} \mathrm{H}$ NMR spectra of both the compounds $3 \& 5$ exhibited a new resonated signal at $\delta 4-3.5 \mathrm{ppm}$ for the presence of $\mathrm{CH}_{2}$ of 4 -thiazolidinone with lacks of $\delta$ at $9.5 \mathrm{ppm}$ of $\mathrm{CH}=\mathrm{N}$, which confirm that structures.

A ${ }^{13} \mathrm{C}$ NMR spectrum of compound 4 recorded a different type of carbons 
which confirm that structure which gives us a good indication about that structure (Figure 4).

Also, mass fragmentation pattern of compound 4 showed the molecular ion peak at $\mathrm{m} / \mathrm{e} 505$ with the base peak at $\mathrm{m} / \mathrm{z} 187$ attribute to antipyrine ion (Figure 5 \& Figure 6).

In addition, ${ }^{13} \mathrm{C}$ NMR spectrum of compound 5 recorded mainly resonated signals at $\delta 119-118 \mathrm{ppm}$ for cyclic C-S-C with $\delta$ at 70 and $170 \mathrm{ppm}$ for $\mathrm{CH}_{2}$ and $\mathrm{C}=\mathrm{O}$ carbons.

Finally, mass fragmentation pattern of compound 5 recorded the molecular ion peak with the base peak at $187 \mathrm{~m} / \mathrm{z}$ attribute to 1,5-dimethyl-3-oxo-2-phenylpyrazol ion (Figure $7 \&$ Figure 8).

It is interest that, $\mathrm{UV}$-absorption spectral study showed that $\lambda_{\max }$ of compound 4 is higher than $\lambda_{\max }$ of compound 5 , which attribute to inhibition of the conjugated system formed of $\mathbf{4}$ to an isolated thiazolidinone moiety.

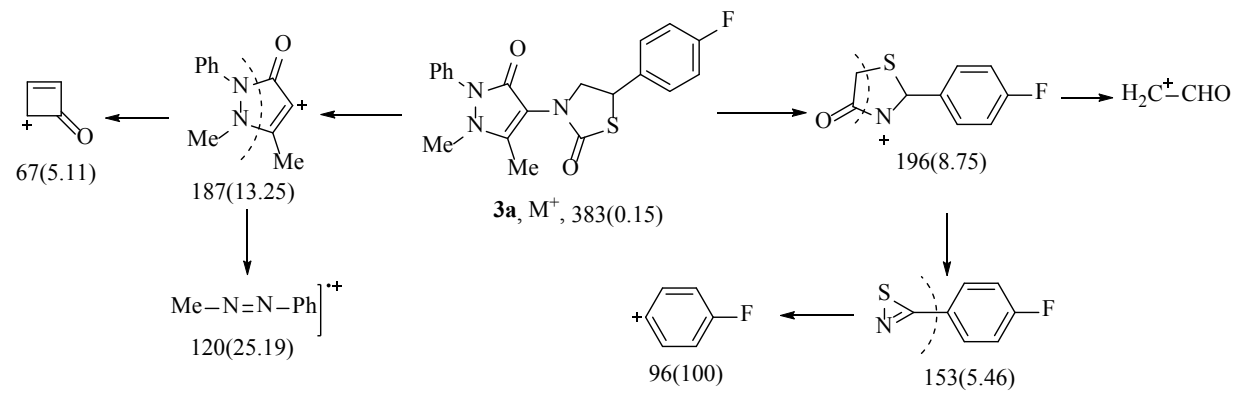

Figure 3. Mass fragmentation pattern of compound 3a.

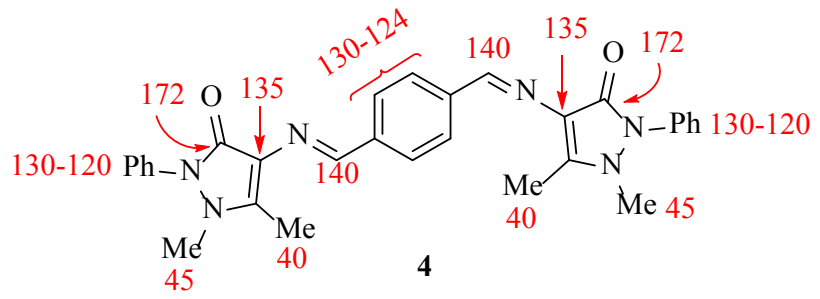

Figure $4 .{ }^{13} \mathrm{C}$ NMR data $(\delta \mathrm{ppm})$ of compound 4 .

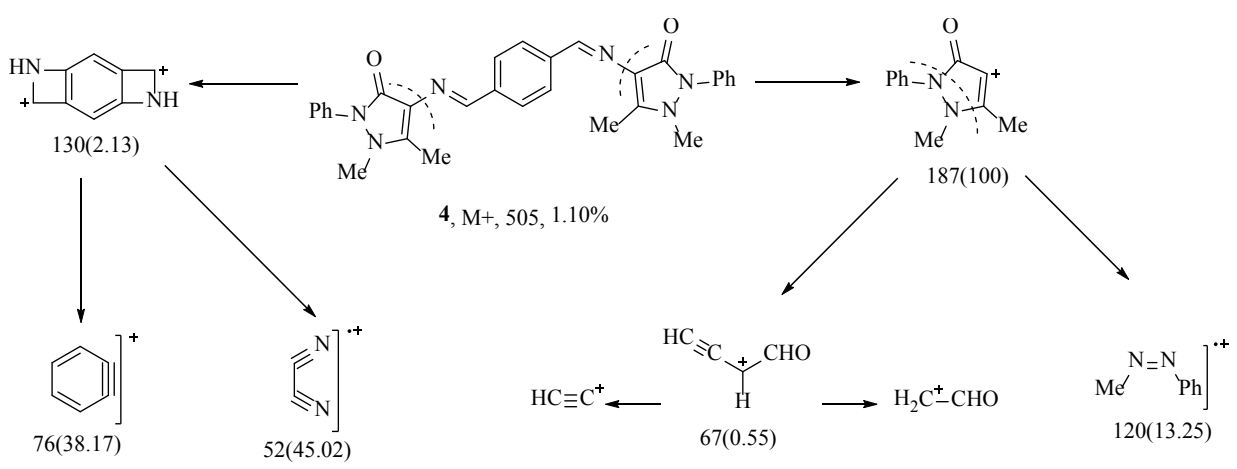

Figure 5. Mass fragmentation pattern of compound 4. 


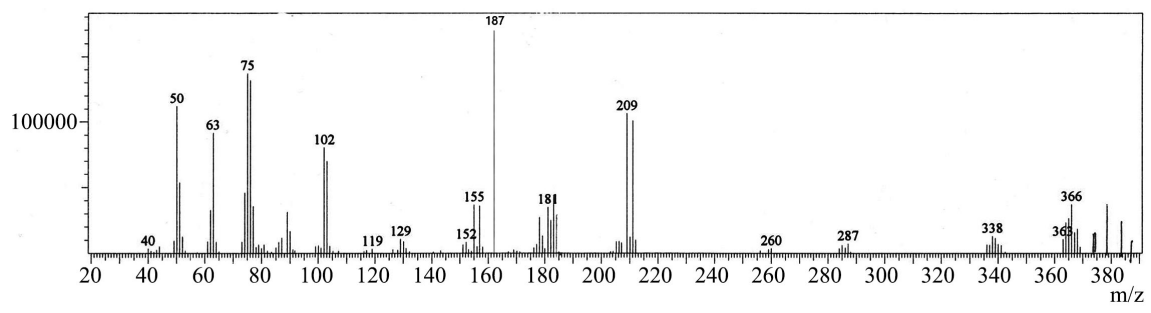

Figure 6. Mass Spectrum of compound 4.

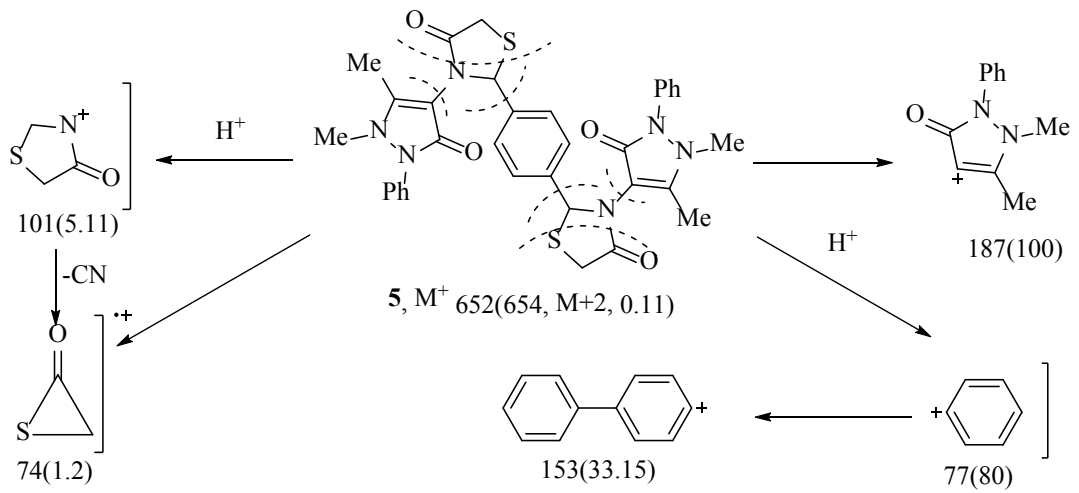

Figure 7. Mass fragmentation pattern of compound 5.

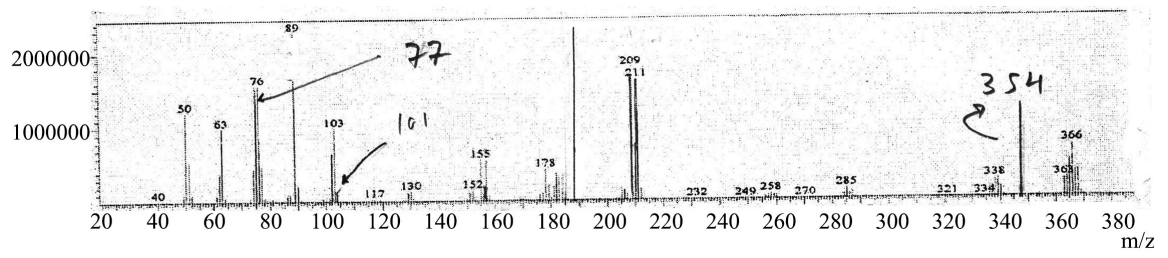

Figure 8. Mass Spectrum of compound 5.

\section{Biological Inhibition of Purine Metabolism Enzymes}

All the synthesized compounds evaluated as enzymatic inhibitors towards purine metabolic by bacteria. The antibacterial effects can be deduced through one of five fundamental mechanisms 1) inhibition of cell-wall synthesis 2) interference with the function of the cytoplasmic membrane 3) inhibition of protein synthesis and 4) interference with cytoplasmic metabolism and final 5) inhibition of nucleic acid fission. A possible mechanism of action is the formation of a type of complexes between different centers, one from the positive microorganisms and the other from the negative drug [16]. According to these finding, the present work aimed to synthesize some new Schiff's bases and the corresponding thiazolidin-4-ones bearing antipyrine moiety and evaluate their enzymatic properties towards purine metabolic enzymes by bacteria. The new compounds tested at concentrations 32 and $131 \mu \mathrm{M}$ in the case of $E$. coli (PNP) and $45-65 \mu \mathrm{M}$ in the case of XAO [17]. Since the analogs Schiff's base and the corresponding thiazolidin-4-ones, e.q. Allopurinol has therapeutic applications as known as potent inhibitors of the xanthine oxidase (XAO) Enzyme [18]. The 
$\mathrm{IC}_{50}$ values are given in (Table 1), were insensitive to the concentration of the $\mathrm{m}^{7}$ Guo substrate, indicating a non-competitive type of the inhibition. Enzymatic phosphorolysis of $\mathrm{m}^{7}$ Guo assayed in $50 \mu \mathrm{M}$ phosphate $\mathrm{pH}$ 7.0.

From the results obtained, we can be concluded that the tested compounds have indirect effects on the role of the tested organism. The high $\mathrm{IC}_{50}$ values indicated that the good inhibition toward organism and vice versa low $\mathrm{IC}_{50}$ values give good to moderate inhibition for purine metabolism enzymes.

The order of the inhibitionactivity is as $3 \mathrm{a}>4>2 \mathrm{a}>5>3 \mathrm{f}>3 \mathrm{e}$. A higher activity of compound $3 \mathrm{a}$ may attribute to the presence of F-atom and NCS of thiazolidin-4-one. Also, both compounds 4 and 5 refer to the presence of two thiazolidin-4-ones and two Schiff bases units.

\section{Experimental}

The melting point recorded on Stuart scientific SMP3 (Bibby, UK) melting point apparatus and reported as uncorrected. A Perkin Elmer (Lambda EZ-2101) double beam spectrophotometer $(190-1100 \mathrm{~nm})$ used for recording the electronic spectra. A Perkin Elmer model RXI-FT-IR 55,529 $\mathrm{cm}^{-1}$ used for recording the FT-IR spectra. A Brucker advance DPX $400 \mathrm{MHz}$ using TMS as an internal standard for recording the ${ }^{1} \mathrm{H} /{ }^{13} \mathrm{C}$ NMR spectra in $\mathrm{CDCl}_{3}$ ( $\delta$ in ppm). AGCMS-QP 1000 Ex model used for recording the mass spectra. Elemental analysis performed on Micro Analytical Center of National Reaches Center-Dokki, Cairo, Egypt.

\subsection{Schiff's Bases 2a-2f}

A mixture of compound $1(0.05 \mathrm{~mol})$ and selective aromatic and heteropolyaldehydes $(0.05 \mathrm{~mol})$ in abs. EtOH $(100 \mathrm{ml})$ heated under reflux for $1 \mathrm{~h}$, cooled. The solid obtained filtered off and crystallized from suitable solvent to give $2 \mathrm{a}-\mathbf{2 f}$ respectively.

Table 1. The enzymatic effect of the new compounds on the bacterial (E. coli) purine-nucleoside phosphorylase and xanthine oxidase from buttermilk.

\begin{tabular}{|c|c|c|c|c|c|c|}
\hline \multirow{2}{*}{ Compound } & \multicolumn{3}{|c|}{ Inhibition of E. Coli (PNP) } & \multicolumn{3}{|c|}{ Inhibition of XAO } \\
\hline & $\begin{array}{l}\text { Substrate } \\
\text { M2 Guo }\end{array}$ & $\begin{array}{l}\text { Conc. } \\
(\mu \mathrm{M})\end{array}$ & $\begin{array}{l}\mathrm{IC}_{50} \\
(\mu \mathrm{M})\end{array}$ & $\begin{array}{c}\text { Substrate } \\
(\mathrm{Hx})\end{array}$ & $\begin{array}{l}\text { Conc. } \\
(\mu \mathrm{M})\end{array}$ & $\begin{array}{l}\mathrm{IC}_{50} \\
(\mu \mathrm{M})\end{array}$ \\
\hline $2 a$ & $\sim$ & $\begin{array}{c}32 \\
131\end{array}$ & $\begin{array}{l}\sim 500 \\
\sim 600\end{array}$ & $\sim$ & 50 & $\sim 700$ \\
\hline $3 a$ & $\sim$ & $\begin{array}{c}32 \\
131\end{array}$ & $\begin{array}{l}\sim 700 \\
\sim 700\end{array}$ & $\sim$ & 45 & $\sim 900$ \\
\hline $3 f$ & $\sim$ & $\begin{array}{c}32 \\
131\end{array}$ & $\begin{array}{l}\sim 500 \\
\sim 600\end{array}$ & $\sim$ & 60 & $\sim 500$ \\
\hline $3 e$ & $\sim$ & $\begin{array}{c}32 \\
131\end{array}$ & $\begin{array}{l}\sim 400 \\
\sim 500\end{array}$ & $\sim$ & 65 & $\sim 500$ \\
\hline 4 & $\sim$ & $\begin{array}{c}32 \\
131\end{array}$ & $\begin{array}{l}\sim 700 \\
\sim 800\end{array}$ & $\sim$ & 48 & $\sim 700$ \\
\hline 5 & $\sim$ & $\begin{array}{c}32 \\
131\end{array}$ & $\begin{array}{l}\sim 600 \\
\sim 700\end{array}$ & $\sim$ & 60 & $\sim 600$ \\
\hline
\end{tabular}


2a. EtOH, yield $83 \%$. M.p: $210^{\circ} \mathrm{C}-212^{\circ} \mathrm{C}$. UV (EtOH $\left.\lambda_{\max } \mathrm{nm}\right): 320$. FT-IR (ATR) $\bar{v} \mathrm{~cm}^{-1}: 3060,3040$ (aromatic $\mathrm{CH}$ ), 2950, 2880 (aliphatic $\mathrm{CH}_{3}$ ), 1670 $(\mathrm{C}=\mathrm{O}), 1580(\mathrm{C}=\mathrm{N}), 1200$ (bending $\mathrm{CH}=\mathrm{C}), 1250(\mathrm{C}-\mathrm{F}) .{ }^{1} \mathrm{H}$ NMR $\left(\mathrm{CDCl}_{3}\right) \delta$ ppm: $9.40(s, 1 \mathrm{H},-\mathrm{CH}=\mathrm{C}), 8.20,8.00(d, d, \mathrm{H}$ adjacent to F-aromatic), $6.8-6.6$ $(m, 2 \mathrm{H}$, aromatic $\mathrm{H}$ ), $6.5-6.2$ ( $m$, $5 \mathrm{H}$, phenyl protons), 2.2, 3.2 (each $s$, Me-C \& Me-N). Anal. Calcd. for $\mathrm{C}_{18} \mathrm{H}_{16} \mathrm{FN}_{3} \mathrm{O}$ (309): C, 69.89; H, 5.21; F, 6.14; N, 13.58\%. Found: C, $69.45 ; \mathrm{H}, 5.10 ; \mathrm{F}, 6.07 ; \mathrm{N}, 13.38 \%$.

2b. THF, yield $88 \%$. M.p: $227^{\circ} \mathrm{C}-229^{\circ} \mathrm{C}$. FT-IR (ATR) $\bar{v} \mathrm{~cm}^{-1}: 2900,2880$ (aliphatic $\left.\mathrm{CH}_{3}\right), 1680(\mathrm{C}=\mathrm{O}), 1610($ exo $\mathrm{CH}=\mathrm{N}), 880,830,810(\mathrm{ArH}), 780$ (C-Br). Anal. Calcd. for $\mathrm{C}_{18} \mathrm{H}_{16} \mathrm{BrN}_{3} \mathrm{O}$ (369): C, 58.39; H, 4.36; $\mathrm{Br}, 21.58 ; \mathrm{N}$, $11.35 \%$. Found: C, 58.31; H, 4.26; Br, 21.21; N, 10.99\%.

2c. EtOH, yield $87 \%$. M.p: $128^{\circ} \mathrm{C}-130^{\circ} \mathrm{C}$. FT-IR (ATR) $\bar{v} \mathrm{~cm}^{-1}: 2980,2870$ (aliphatic $\left.\mathrm{CH}_{3}\right), 1670(\mathrm{C}=\mathrm{O}), 1620($ exo $\mathrm{CH}=\mathrm{N}), 870,830(\mathrm{ArH}), 700(\mathrm{C}-\mathrm{Cl})$. Anal. Calcd. for $\mathrm{C}_{18} \mathrm{H}_{16} \mathrm{ClN}_{3} \mathrm{O}$ (325): C, 66.36; H, 4.95; Cl, 10.88; N, $12.90 \%$. Found: C, 65.99; $\mathrm{H}, 4.82 ; \mathrm{Cl}, 10.82 ; \mathrm{N}, 12.73 \%$.

2d. $\mathrm{MeOH}$, yield $88 \%$. M.p: $253^{\circ} \mathrm{C}-255^{\circ} \mathrm{C}$. FT-IR (ATR) $\bar{v} \mathrm{~cm}^{-1}: 2960,2880$ (aliphatic $\left.\mathrm{CH}_{3}\right), 1680(\mathrm{C}=\mathrm{O}), 1610($ exo $\mathrm{CH}=\mathrm{N}), 910,860,830(\mathrm{ArH})$. Anal. Calcd for $\mathrm{C}_{20} \mathrm{H}_{18} \mathrm{~N}_{4} \mathrm{O}$ (330): C, 72.71; H, 5.49; N, 16.96\%. Found: C, 72.68; H, $5.38 ; \mathrm{N}, 16.77 \%$.

2e. $\mathrm{MeOH}$, yield $89 \%$. M.p: $196^{\circ} \mathrm{C}-198^{\circ} \mathrm{C}$. FT-IR (ATR) $\bar{v} \mathrm{~cm}^{-1}: 2970,2880$ (aliphatic $\left.\mathrm{CH}_{3}\right), 1680(\mathrm{C}=\mathrm{O}), 1620($ exo $\mathrm{CH}=\mathrm{N}), 820,810(\mathrm{ArH})$. Anal. Calcd. for $\mathrm{C}_{27} \mathrm{H}_{26} \mathrm{~N}_{4} \mathrm{O}$ (422): C, 76.75: H, 6.20: N, 13.26 \%. Found: C, 76.45; H, 5.99; N, $13.15 \%$.

2f. THF, yield $85 \%$. M.p: $165^{\circ} \mathrm{C}-167^{\circ} \mathrm{C}$. FT-IR (ATR) $\bar{v} \mathrm{~cm}^{-1}: 2975,2890$ (aliphatic $\mathrm{CH}_{3}$ ), $1678(\mathrm{C}=\mathrm{O}), 1618$ (exo $\left.\mathrm{CH}=\mathrm{N}\right), 1200$ - 1100 (C-S-C), 834, 810 (ArH). Anal. Calcd. for $\mathrm{C}_{24} \mathrm{H}_{20} \mathrm{~N}_{4} \mathrm{SO}$ (412): C, 69.88; H, 4.89; N, 13.58; S, 7.77\%. Found: C, 69.81; H, 4.80; N, 13.29; S, 7.55\%.

\subsection{3-(1'-Phenyl-2',3'-Dimethyl-5'-0xo-Pyrazol-4'-yl)- Thiazolidin-4-Ones (3a,3e,3f)}

A mixture of $2 \mathrm{a}, 2 \mathrm{e} \& 2 \mathbf{f}(0.01 \mathrm{~mol})$ and mercaptoacetic acid $(0.15 \mathrm{~mol})$ in dioxane $(70 \mathrm{ml})$ heated under reflux for $6-8 \mathrm{~h}$, cooled, then neutralized with eq. $\mathrm{NaHCO}_{3}$. The solid produced filtered off and crystalized from suitable solvent to give yellowish crystals $3 \mathrm{a}, 3 \mathrm{e} \& 3 \mathrm{f}$ respectively.

3a. Dioxane, yield $60 \%$ : M.p: $185^{\circ} \mathrm{C}-187^{\circ} \mathrm{C}$. UV $\left(\lambda_{\max } \mathrm{nm}\right) 275$. FT-IR (ATR) $\bar{v} \mathrm{~cm}^{-1}:$ 3060, 3040 (aromatic $\mathrm{CH}$ ), 2950, 2840 (aliphatic $\mathrm{CH}$ ), 1700, 1670 (2C=O), 1250 (C-F), 1190 (C-S-C), 700 (C-F). ${ }^{1} \mathrm{H}$ NMR $\left(\mathrm{CDCl}_{3}\right) \delta$ ppm: 8.2, 8.0, 6.8 - $6.4\left(\mathrm{~m}, 9 \mathrm{H}\right.$, aromatic protons), $4.8\left(\mathrm{~s}, 1 \mathrm{H}\right.$, exo), $4.0\left(\mathrm{~m}, 2 \mathrm{H}, \mathrm{CH}_{2}\right), 3.1(\mathrm{~s}, 3 \mathrm{H}$, $\mathrm{N}-\mathrm{Me}), 2.3(s, 3 \mathrm{H}, \mathrm{C}-\mathrm{Me}) .{ }^{13} \mathrm{C} \mathrm{NMR}\left(\mathrm{CDCl}_{3}\right) \delta \mathrm{ppm}: 172(\mathrm{C}=\mathrm{O}), 158(\mathrm{C}=\mathrm{O}), 135$ $(\mathrm{C}=\mathrm{C}), 130$ - 122 (aromatic carbons), 125 (C-F). 118 (C-S-C), $62\left(\mathrm{CH}_{2}\right), 40,38$ (-C-N, -C-C). M/S (m/e, Int. \%): 383 (0.15), 196 (8.75), 187 (13.25), 120 (25.19), 95 (100), 67 (5.11). Anal. Calcd. for $\mathrm{C}_{20} \mathrm{H}_{18} \mathrm{FN}_{3} \mathrm{O}_{2} \mathrm{~S}$ (383): C, 62.65; H, 4.73; F, $4.95 ; \mathrm{N}, 10.96 ; \mathrm{S}, 8.36 \%$. Found, C, 62.49; H, 4.55; F, 4.81; N, 10.79; S, 8.11\%. 
3e. $\mathrm{EtOH}$ : yield 55\%, M.p: $210^{\circ} \mathrm{C}-212^{\circ} \mathrm{C}$. FT-IR (ATR) $\bar{v} \mathrm{~cm}^{-1}: 2982,2876$ (aliphatic $\mathrm{CH}_{3}$ ), 1710, $1678(2 \mathrm{C}=\mathrm{O}), 1200-1180$ (C-S-C), 912, 820 (ArH). Anal. Calcd. for $\mathrm{C}_{29} \mathrm{H}_{28} \mathrm{~N}_{4} \mathrm{O}_{2} \mathrm{~S}$ (496): C, 70.14; H, 5.68; N, 11.28; S, 6.46\%. Found: C, 70.01; H, 5.12; N, 11.01; S, 6.29\%.

3f. $\mathrm{MeOH}$, yield 50\%, M.p: $180^{\circ} \mathrm{C}-182^{\circ} \mathrm{C}$. FT-IR (ATR) $\bar{v} \mathrm{~cm}^{-1}: 2980,2880$ (aliphatic $\mathrm{CH}_{3}$ ), 1700, 1675 (2C=O), 1200 - 1190 (C-S-C), 880, 830, 810 (ArH). Anal. Calcd. for $\mathrm{C}_{26} \mathrm{H}_{22} \mathrm{~N}_{4} \mathrm{O}_{2} \mathrm{~S}_{2}$ (486): C, 64.18; H, 4.56; N, 11.51; S, $13.18 \%$. Found: C, 63.95; H, 4.12; N, 11.33; S, 12.98\%.

\subsection{4,4'-((1,4-Phenylenebis(Methaneylylidene)) Bis(Azaneylylidene))Bis(1,5-Dimethyl-2-Phenyl-1,2- Dihydro-3H-Pyrazol-3-One) (4)}

Compound 1 (0.02 mol) and terphthaldehyde $(0.01 \mathrm{~mol})$ in abs. EtOH $(50 \mathrm{ml})$ warmed for $30 \mathrm{~min}$, then cooled. The solid produced filtered off and crystallized from $\mathrm{AcOH}$ to give 4, yield 90\%, M.p: $222^{\circ} \mathrm{C}-224^{\circ} \mathrm{C}$. UV (EtOH $\lambda_{\max }$ nm) 396. FT-IR (ATR) $\bar{v} \mathrm{~cm}^{-1}: 3175$ - 3040, 3035 - 3025 (aromatic CH), 1655 (azomethine $\mathrm{HC}=\mathrm{N}), 1650(\mathrm{C}=\mathrm{O}), 1590-1575(\mathrm{C}=\mathrm{N}), 2980,2915$ (str. Aliphatic $\left.\mathrm{CH}_{3}\right), 1480-1440$ (bending $\left.\mathrm{CH}_{3}\right) .{ }^{1} \mathrm{H}$ NMR $\left(\mathrm{CDCl}_{3}\right) \delta \mathrm{ppm}: 9.40(s, 1 \mathrm{H}$, $\mathrm{CH}=\mathrm{N}), 7.90-6.80(m, 14 \mathrm{H}$, aromatic $\mathrm{CH}), 3.00(s, 3 \mathrm{H}, \mathrm{N}-\mathrm{Me}), 2.25(s, 3 \mathrm{H}$, $\mathrm{C}-\mathrm{Me}) \cdot{ }^{13} \mathrm{C}$ NMR $\left(\mathrm{CDCl}_{3}\right) \delta \mathrm{ppm}: 172(\mathrm{C}=\mathrm{O}), 140(\mathrm{CH}=\mathrm{N}), 135(\mathrm{C}=\mathrm{C}$ of pyrazole), 130 - 120 (aromatic carbons) $45(\mathrm{Me}-\mathrm{N}), 40(\mathrm{Me}-\mathrm{C}) . \mathrm{M} / \mathrm{S}(\mathrm{m} / \mathrm{z}$, Int. \%): $505\left(\mathrm{M}^{+1}, 1.01\right), 187$ (100), 120 (13.25), 76 (38.7), 67 (0.55), 52 (45.00). Anal. calcd. for $\mathrm{C}_{30} \mathrm{H}_{28} \mathrm{~N}_{6} \mathrm{O}_{2}$ (504): C, 71.41; H, 5.59; N, 16.66\%. Found, C, 70.96; H, $5.48 ; \mathrm{N}, 16.47 \%$.

\subsection{2,2'-(1,4-Phenylene)Bis(3-(1,5-Dimethyl-3-0xo-2-Phenyl-2,3- Dihydro-1H-Pyrazol-4-yl)Thiazolidin-4-One) (5)}

Compound $4(0.01 \mathrm{~mol})$, mercaptoacetic acid $(0.04 \mathrm{~mol})$ in dioxane $(50 \mathrm{ml})$ heated under reflux for $8-10 \mathrm{~h}$, cooled then neutralized by aq. $\mathrm{NaHCO}_{3}$. The solid obtained filtered off and crystallized from $\mathrm{MeOH}$, to give 5, yield $66 \%$, M.p: $275^{\circ} \mathrm{C}-277^{\circ} \mathrm{C}$. FT-IR (ATR) $\bar{v} \mathrm{~cm}^{-1}$ : 3080, 3040 (aromatic CH), 2910, 2850 (aliphatic CH), 1700, $1660(2 \mathrm{C}=\mathrm{O}), 1480,1440$ (deform. $\left.\mathrm{CH}_{2}\right), 1190$ (C-S-C), 880, 820 (aromatic rings). ${ }^{13} \mathrm{C} \mathrm{NMR}\left(\mathrm{CDCl}_{3}\right) \delta$ ppm: 172, $162(2 \mathrm{C}=\mathrm{O}), 132$ $(\mathrm{C}=\mathrm{C}), 130$ - 126 (aromatic carbons), $119(\mathrm{C}-\mathrm{S}-\mathrm{C}) .70\left(\mathrm{CH}_{2}\right), 40$ \& $38(\mathrm{Me}-\mathrm{N} \&$ Me-C). M/S (m/z, Int \%): 654 (0.11), 187 (100), 176 (1.5), 159 (2.11), 101 (5.11), 76 (80.13), 74 (1.2). Anal. Calcd. for $\mathrm{C}_{34} \mathrm{H}_{32} \mathrm{~N}_{6} \mathrm{O}_{4} \mathrm{~S}_{2}$ (652): C, 62.56; H, 4.94; N, 12.87; S, 9.82\%. Found: C, 62.21; H, 4.63; N, 12.59; S, 9.74\%.

\subsection{Formation of Bis-Compound 5}

A mixture of compound 1 (0.02 mol), 1,4-terphthaldehyde $(0.01 \mathrm{~mol})$, and excess of mercaptoacetic acid in EtOH/ drops piperidine heated under reflux for $24 \mathrm{~h}$, cooled. Then treated with aq. $\mathrm{K}_{2} \mathrm{CO}_{3}$ followed by addition of drops of $\mathrm{HCl}$. The solid obtained, filtered off and crystallized from EtOH to give 5. Melting point of both methods and a mixed melting point not changed. 


\section{Conclusion}

Some new 4-thiazolidinones and bis-compounds have been synthesized and derived from condensation of 4-aminoantipyrine with aromatic aldehyde followed by cycloaddition of thioglycolic acid in a non-polar solvent. Fluorine substituted thiazolidin-4-one moiety bearing antipyrine nucleus enhanced the enzymatic effects of the bacteria, which agreed with last results published [19] [20] [21].

\section{Acknowledgements}

Many thanks for King Abdulaziz University, Jeddah, SA.

\section{Conflicts of Interest}

The authors declare no conflicts of interest regarding the publication of this paper.

\section{References}

[1] Abdel-Rahman, R.M. (2001) Chemoselective Heterocyclization and Pharmacological Activities of New Heterocycles: A Review. Part V-Synthesis of Biocidal 4-Thiazolidinones Derivatives. Bollettino Chimico Farmaceutico, 140, 401-410.

[2] Kumar, K.S., Rao, A.L. and Rao, M.B. (2018) Design, Synthesis, Biological Evaluation and Molecular Docking Studies of Novel 3-Substituted-5-[(Indol-3-yl) Methylene]-Thiazolidine-2,4-Dione Derivatives. Heliyon, 4, e00807. https://doi.org/10.1016/j.heliyon.2018.e00807

[3] Abdel-Rahman, R.M. and Ali, T.E. (2013) Synthesis and Biological Evaluation of Some New Polyfluorinated 4-Thiazolidinone and $\alpha$-Aminophosphonic acid Derivatives. Monatshefte für Chemie-Chemical Monthly, 144, 1243-1252. https://doi.org/10.1007/s00706-013-0934-6

[4] Makki, M.S., Alfooty, K., Abdel-Rahman, R.M. and El-Shahawi, M. (2016) Synthesis, Voltammetric and Analytical Applications of Some Fluorine Substituted Spirosteroidalthiazolidin-4-One Derivatives of Sulfa Drugs. Journal of the Chinese Chemical Society, 63, 189-198. https://doi.org/10.1002/jccs.201500240

[5] Taib, L.A. (2018) Synthesis and Antifungal Activity of Some New Fluorine-Substituted 4-Thiazolidinone Bearing 1,2,4-Triazinone. International Journal of Organic Chemistry, 8, 170-175. https://doi.org/10.4236/ijoc.2018.81012

[6] Sakthivel, M., Ramaraj, S., Chen, S.-M. and Dinesh, B. (2018) Synthesis of Rose Like Structured $\mathrm{LaCoO}_{3}$ Assisted Functionalized Carbon Nanofiber Nanocomposite for Efficient Electrochemical Detection of Anti-Inflammatory Drug 4-Aminoantipyrine. Electrochimica Acta, 260, 571-581. https://doi.org/10.1016/j.electacta.2017.11.122

[7] Aiad, I.A., Tawfik, S.M., El-Shafie, M. and Rhman, A.L.A. (2018) 4-Aminoantipyrine Derived Cationic Surfactants: Synthesis, Characterization, Surface Activity and Screening for Potential Antimicrobial Activities. Egyptian Journal of Petroleum, 27, 327-334. https://doi.org/10.1016/j.ejpe.2017.05.006

[8] El-Rehim, S.A., Ibrahim, M.A.M. and Khaled, K.F. (1999) 4-Aminoantipyrine as an Inhibitor of Mild Steel Corrosion in $\mathrm{HCl}$ Solution. Journal of Applied Electrochemistry, 29, 593-599. https://doi.org/10.1023/A:1003450818083

[9] Tyagi, M., Chandra, S., Tyagi, P., Akhtar, J., Kandan, A. and Singh, B. (2017) Synthesis, Characterization and Anti-Fungal Evaluation of Ni (II) and Cu (II) Com- 
plexes with a Derivative of 4-Aminoantipyrine. Journal of Taibah University for Science, 11, 110-120. https://doi.org/10.1016/j.jtusci.2015.11.003

[10] Alam, M.S., Lee, D.-U. and Bari, M.L.(2014) Antibacterial and Cytotoxic Activities of Schiff Base Analogues of 4-Aminoantipyrine. Journal of the Korean Society for Applied Biological Chemistry, 57, 613-619. https://doi.org/10.1007/s13765-014-4201-2

[11] Lim, J.Y., Yoon, J.W. and Hovde, C.J. (2010) A Brief Overview of Escherichia coli O157:H7 and Its Plasmid O157. Journal of Microbiology and Biotechnology, 20, 5-14.

[12] Youssef, A.M., White, M.S., Villanueva, E.B., El-Ashmawy, I.M. and Klegeris, A. (2010) Synthesis and Biological Evaluation of Novel Pyrazolyl-2,4-Thiazolidinediones as Anti-Inflammatory and Neuroprotective Agents. Bioorganic \& Medicinal Chemistry, 18, 2019-2028. https://doi.org/10.1016/j.bmc.2010.01.021

[13] Wang, Z., Liu, Z., Lee, W., Kim, S.-N., Yoon, G. and Cheon, S.H. (2014) Design, Synthesis and Docking Study of 5-(Substituted Benzylidene) Thiazolidine-2,4-Dione Derivatives as Inhibitors of Protein Tyrosine Phosphatase 1B. Bioorganic \& Medicinal Chemistry Letters, 24, 3337-3340. https://doi.org/10.1016/j.bmcl.2014.05.099

[14] Wu, Y., Tai, H.-H. and Cho, H. (2010) Synthesis, and SAR of Thiazolidinedione Derivatives as 15-PGDH Inhibitors. Bioorganic \& Medicinal Chemistry, 18, 1428 1433. https://doi.org/10.1016/j.bmc.2010.01.016

[15] Sucheta Tahlan, S. and Verma, P.K. (2017) Biological Potential of Thiazolidinedione Derivatives of Synthetic Origin. Chemistry Central Journal, 11, 130.

https://doi.org/10.1186/s13065-017-0357-2

[16] Dipalma, J.R., Digregorio, G. and Basic, J. (1990) Pharmacology in Medicine. 3rd Edition, Mc Graw-Hill, New York.

[17] Kulikowska, E., Bzowska, A., Wierzchowski, J. and Shugar, D. (1986) Properties of Two Unusual, and Fluorescent, Substrates of Purine-Nucleoside Phosphorylase: 7-Methylguanosine and 7-Methylinosine. Biochimica et Biophysica Acta-Protein Structure and Molecular Enzymology, 874, 355-363. https://doi.org/10.1016/0167-4838(86)90035-X

[18] Borges, F., Fernandes, E. and Roleira, F. (2002) Progress Towards the Discovery of Xanthine Oxidase Inhibitors. Current Medicinal Chemistry, 9, 195-217. https://doi.org/10.2174/0929867023371229

[19] Ali, T.E. and Abdel-Rahman, R.M. (2014) Synthesis and Antioxidant Activities of Some Novel Fluorinated Spiro [Oxindole-Thiazolidine] Fused with Sulfur and Phosphorus Heterocycles. Journal of Sulfur Chemistry, 35, 399-411. https://doi.org/10.1080/17415993.2014.896363

[20] Abdel-Rahman, R.M., Angawi, R.F. and Al-Mehmadi, A.R. (2017) Synthesis and Biological Evaluation of Fluorine Substituted Pyrazolo[4,3-e][1,2,4] Triazines as Purine Analogues. Journal of Saudi Chemical Society, 21, 495-503. https://doi.org/10.1016/j.jscs.2016.11.004

[21] Makki, M.S.T., Abdel-Rahman, R.M. and Alshammari, N.A.H. (2019) Synthesis of Novel Fluorine Compounds Substituted-4-Thiazolidinones Derived from Rhodanine Drug as Highly Bioactive Probes. Current Organic Synthesis, 16, 1-10. https://doi.org/10.2174/1570179416666190312150046 